\title{
Amniotic membrane as a biological scaffold for dental pulp stem cell transplantation in ocular surface reconstruction
}

\author{
Membrana amniótica como substrato biológico para o transplante \\ de células-tronco da polpa do dente de leite na reconstrução da \\ superfície ocular
}

\author{
Babyla Geraldes Monteiro,2, Renata Ruoco Loureiro³, Priscila Cardoso Cristovam³, Joyce Luciana Covre ${ }^{3}$, \\ José Álvaro Pereira Gomes³, Irina Kerkis \\ 1. Laboratório de Genética, Instituto Butantan, São Paulo, SP, Brasil. \\ 2. Departamento de Morfologia, Universidade Federal de São Paulo, São Paulo, SP, Brasil. \\ 3. Centro Avançado de Superfície Ocular (CASO), Departamento de Oftalmologia e Ciências Visuais, Universidade Federal de São Paulo, São Paulo, \\ SP, Brasil.
}

\begin{abstract}
Purpose: To evaluate the ability of human immature dental pulp stem cells, which are mesenchymal stem cells of neural crest origin, to differentiate into the corneal epithelium for purposes of corneal transplantation and tissue engineering when cultured on de-epithelized amniotic membranes. Methods: We compared the immunophenotypes (ABCG2, $\mathrm{K} 3 / 12$, and vimentin) of cells grown on amniotic membranes or plastic surfaces under serum-free conditions or in culture media containing serum or serum replacement components. Results: Immature dental pulp stem cells grown on amniotic membranes under basal conditions are able to maintain their undifferentiated state. Our data also suggest that the culture medium used in the present work can modulate the expression of immature dental pulp stem cell markers, thus inducing epithelial differentiation of these cells in vitro. Conclusions: Our results suggest that the amniotic membrane is a good choice for the growth and transplantation of mesenchymal stem cells, particularly immature dental pulp stem cells, in clinical ocular surface reconstruction.
\end{abstract}

Keywords: Corneal epithelia; Limbus cornae; Stem cell; Dental pulp; Amniotic membrane; Ocular surface

Submitted for publication: August 29, 2017

Accepted for publication: June 22, 2018

Funding: This study was supported by FAPESP process number 2010/08595-5.

Disclosure of potential conflicts of interest: None of the authors have any potential conflicts of interest to disclose.

Corresponding author: Irina Kerkis

Laboratório de Genética. Instituto Butantan. Av. Vital Brasil 1500 - São Paulo, SP 05503-900 - Brasil - E-mail: irina.kerkis@butantan.gov.br

Approved by the following research ethics committee: Instituto Butantan (\# 715/10).
RESUMO | Objetivos: Avaliar a capacidade das células-tronco imaturas da polpa do dente de leite que são células-tronco mesenquimais de origem da crista neural, de se diferenciarem no epitélio corneano para fins de transplante de córnea e engenharia de tecidos quando cultivadas em membrana amnióticas desepitelizadas. Métodos: Foram comparamos so imunofenótipo (ABCG2, CK3/12 evimentina) de células cultivadas em membranas amnióticas ou em superfícies plásticas sob condições livres de soro ou em meios de cultura contendo soro ou componentes de substituição de soro. Resultados: Células-tronco imaturas da polpa do dente de leite cultivadas sobre membrana amniótica em condições basais são capazes de manter seu estado indiferenciado. Nossos dados também sugerem que o meio de cultura utilizado no presente trabalho pode modular a expressão de marcadores de células-tronco imaturas da polpa do dente de leite, induzindo a diferenciação epitelial destas células in vitro. Conclusão: Nossos resultados sugerem que a membrana amniótica é uma boa escolha para o crescimento e transplante de células-tronco mesenquimais, particularmente as células-tronco imaturas da polpa do dente de leite, na reconstrução da superfície ocular.

Descritores: Epitélio da córnea; Limbo da córnea; Células-tronco; Polpa dentária; Membrana amniótica

\section{INTRODUCTION}

The amniotic membrane (AM) is the innermost layer of the placenta and comprises a thick basement membrane and avascular stromal matrix. The use of AM is a useful mechanism for ophthalmic surgeons in treating a variety of ocular surface disorders because of its transparent structure and ability to provide a substrate for growth of limbal, corneal, and conjunctival epithelial cells ${ }^{(1-3)}$. 
Autologous tissues from the patient's own cells, such as limbal stem cells (LSCs), are the gold standard for corneal tissue engineering, a field that has greatly evolved in recent years ${ }^{(4)}$. The use of autologous LSCs eliminates the risk of rejection, and the use of allogeneic LSCs requires the administration of systemic and topical immunosuppressants $^{(5-11)}$. Therefore, identifying alternative sources of autologous and allogeneic stem cells to substitute for LSCs is extremely important. Mesenchymal stem cells (MSCs) can aid in overcoming the aforementioned problems and provide additional benefits to the transplantation site ${ }^{(12)}$. MSCs are multipotent cells located in various tissues (bone marrow, adipose tissue, umbilical cord, etc.) of adult organisms and are easily isolated and expanded in vitro ${ }^{(12)}$. MSCs are self-renewable and able to differentiate into other cell types under certain conditions. Furthermore, they are capable of modulating angiogenesis and exhibit anti-inflammatory, anti-apoptotic, and immunomodulatory properties. Standardized MSCs acquired under good manufacturing practice conditions and cryopreserved in large quantities are "off-the-shelf" allogeneic MSCs, making them good candidates for corneal reconstruction ${ }^{(13)}$.

We isolated MSCs, which are denominated human immature dental pulp stem cells (hIDPSCs), from the dental pulp of deciduous teeth ${ }^{(14)}$. Similar to LSCs, hIDPSCs originate in the ectoderm during embryonic development, more precisely, from the neural crest $^{(7)}$. The relatively easy recovery and ex vivo expansion ${ }^{(15)}$, the paracrine properties of hIDPSCs, similar to those of $\mathrm{MSCs}^{(12)}$, and most importantly, the LSC marker expression in these cells warrant further exploration of hIDPSCs in ocular surface reconstruction ${ }^{(16)}$.

We tested the use of AM as a biological scaffold for hIDPSC adhesion and growth in an attempt to improve the clinical application of hIDPSCs in limbal stem cell deficiency (LSCD). The similarity between LSCs and hIDPSCs leads us to examine the effect of the culture media used for LSC culture on hIDPSCs in vitro culture by analyzing the expression of LSCs and corneal epithelial cell markers in hIDPSCs grown on plastic surfaces versus de-epithelialized AM.

\section{METHODS}

\section{Study design}

To evaluate the ability of hIDPSCs to differentiate into corneal epithelium, the hIDPSCs were cultivated on AM or plastic surfaces under the following conditions: (1)
Group A: supplemental hormonal epithelial medium (SHEM); (2) Group B: keratinocyte serum-free medium (KSFM); Group C: EpiLife medium; and Group D: D-MEM KnockOut media (D-MEM/KO) as the control group. The cell immunophenotypes (ABCG2, K3/12, and vimentin) were analyzed by immunofluorescence.

\section{De-epithelialization of the amniotic membrane}

Human AM was obtained following written informed consent from the prospective mother upon cesarean section delivery and prepared under sterile conditions; washed with a balanced salt solution containing penicillin, streptomycin, neomycin, and amphotericin B; placed over a nitrocellulose membrane; and preserved in tissue culture medium and glycerol at a ratio of 1:1 at $-80^{\circ} \mathrm{C}^{(1)}$. The $\mathrm{AM}$ was thawed at room temperature, detached from the nitrocellulose membrane (Figures 1 A-B), and washed two times in phosphate-buffered saline (PBS) prior to use. In order to remove the epithelia, the AM was incubated with EDTA $0.02 \%$ over $2 \mathrm{~h}$ at $37^{\circ} \mathrm{C}$, whereupon the epithelia were mechanically removed. Figure $1 \mathrm{C}$ shows the completely transparent AM following epithelia removal, which was transferred onto tissue culture inserts (Figure 1D) for use as a matrix for hIDPSC growth.

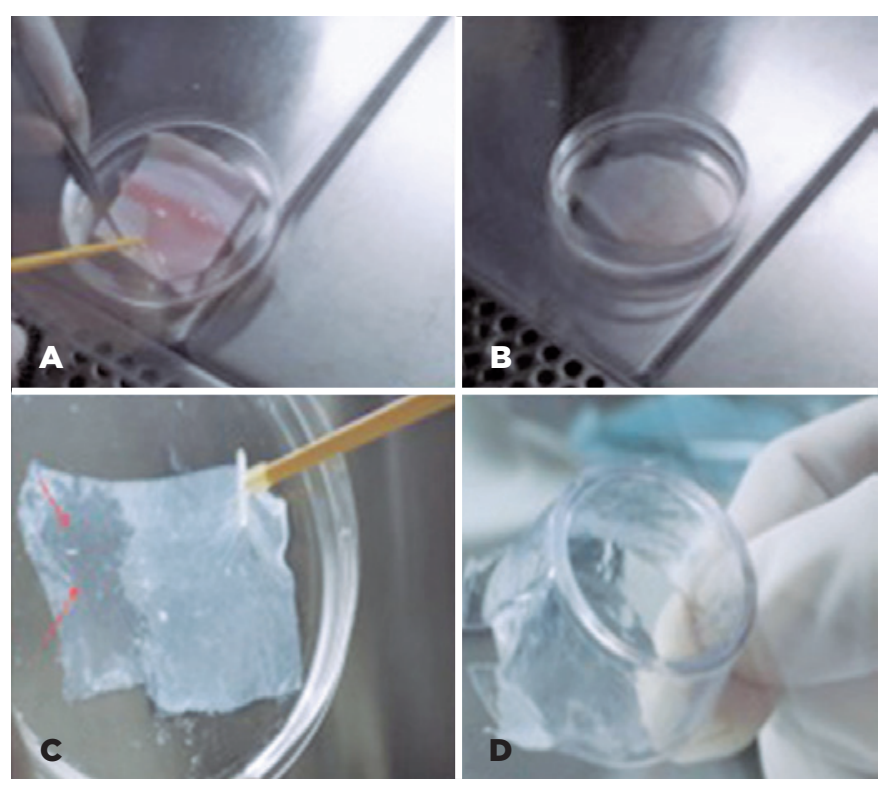

Figure 1. The process of AM de-epithelialization. A) Removal of nitrocellulose membrane. B) AM nitrocellulose membrane free. C) Partial removal of the epithelia (red arrows). D) Complete removal of the epithelia and transference of AM onto tissue culture inserts. 


\section{hIDPSC culture}

hIDPSCs with the karyotype of a woman without a chromosomal abnormality $(2 n=46, X X)$ were isolated from the dental pulp of deciduous teeth and characterized as previously described ${ }^{(14,16)}$. Briefly, hIDPSCs were maintained in Dulbecco's modified eagle medium (D-MEM)/Ham's F-12 (1:1; Invitrogen, Carlsbad, CA, USA), supplemented with $15 \%$ fetal bovine serum (FBS; HyClone, Logan, UT, USA), 100 units/mL penicillin, $100 \mu \mathrm{g} / \mathrm{mL}$ streptomycin, $2 \mathrm{mM}$ L-glutamine, and $2 \mathrm{mM}$ nonessential amino acids (all from Gibco, Grand Island, NY, USA). The culture medium was changed daily, and the cells were replated every 3 days. After reaching $80 \%$ confluence, the cells were washed twice in sterile phosphate-buffered saline (PBS; Gibco; $0.01 \mathrm{M}, \mathrm{pH} 7.4$ ) and enzymatically treated with $0.25 \%$ trypsin/EDTA (Invitrogen), and $10^{5}$ hIDPSCs were seeded onto the previously prepared AM in a $35 \mathrm{~mm}$ Petri Dish (Nunc, Thermo Scientific, Houston, TX, USA). All cultures were incubated at $37^{\circ} \mathrm{C}$ in $5 \% \mathrm{CO}_{2}$ in a high-humidity environment, and experiments using cells at passage 6 or 7 were performed. All experiments with hIDPSCs grown on AM or plastic surfaces, as well as immunofluorescence analyses, were performed in triplicate.

The cells were cultivated for 7 days (pre-transplantation period) because this time interval is optimized for recovery from thawing to transplantation into the injured eye $\mathrm{e}^{(17)}$.

\section{Culture media}

To determine the best culture media for cultivating hIDPSC on AM, we tested the following: A) supplemental hormonal epithelial medium (SHEM), a combination of Dulbecco's modified eagle medium/Ham's F-12 nutrient mixture (D-MEM/F-12; 1:1), supplemented with $5 \mu \mathrm{g} / \mathrm{mL}$ crystalline bovine insulin (Sigma-Aldrich, St. Louis, MO, USA), $30 \mathrm{ng} / \mathrm{mL}$ cholera toxin (Calbiochem, San Diego, CA, USA), $2 \mathrm{ng} / \mathrm{mL}$ epidermal growth factor (EGF, R\&D Systems, Inc., Minneapolis, MN, USA), 0.5\% dimethyl sulfoxide (DMSO, Sigma-Aldrich), $0.5 \mu \mathrm{g} / \mathrm{mL}$ hydrocortisone, $5 \mathrm{ng} / \mathrm{mL}$ sodium selenite, $5 \mu \mathrm{g} / \mathrm{mL}$ Apo-transferrin, and $10 \%$ fetal bovine serum (FBS). B) Keratinocyte serum-free medium (KSFM) containing $0.09 \mathrm{mM}$ calcium supplemented with $30 \mathrm{mg} / \mathrm{mL}$ pituitary bovine extract, $0.2 \mathrm{ng} / \mathrm{mL}$ EGF, 10\% FBS, and ampicillin/streptomycin. C) Epilife medium (Cascade Biologics, Portland, OR, USA), containing $0.06 \mathrm{mM}$ calcium, supplemented with $1 \%$ "human corneal growth supplement," $0.2 \%$ pituitary bo- vine extract, $5 \mathrm{~g} / \mathrm{mL}$ bovine insulin, $0.18 \mathrm{mg} / \mathrm{mL}$ hydrocortisone, $5 \mu \mathrm{g} / \mathrm{mL}$ bovine transferrin, $0.2 \mathrm{ng} / \mathrm{mL}$ EGF, $1 \%$ penicillin G sodium (penicillin G sodium 10,000 g/mL, streptomycin sulfate $25 \mathrm{mg} / \mathrm{mL}$, amphotericin B in $0.85 \%$ $\mathrm{NaCl}$ ), and 5\% FBS. D) D-MEM KnockOut media (D-MEM/ KO) serum-free, supplemented with $1 \%$ penicillin and streptomycin. All reagents were obtained from Invitrogen Corporation, except those indicated in the text.

\section{Immunofluorescence staining}

Cells were grown on glass coverslips or AM up to $70 \%$ confluence, washed in PBS (Gibco), and fixed overnight with $4 \%$ formaldehyde (Sigma). The coverslips were washed three times in Tris-buffered saline (TBS) containing 20 mM Tris- $\mathrm{HCl}$, pH 7.4 (Vetec, Duque de Caxias, RJ, Brazil), $0.15 \mathrm{M} \mathrm{NaCl}$ (Dinâmica Reagent, São Paulo, SP, Brazil), and 0.05\% Tween-20 (Sigma). Cell permeabilization was performed using $0.1 \%$ Triton X-100 (Santa Cruz Biotechnology) for $15 \mathrm{~min}$. Cells were washed three times and incubated for 30 min with $5 \%$ bovine serum albumin (Sigma) in PBS, pH 7.4 (Gibco). The slides were incubated with primary antibodies anti-ABCG2, K3/12, and vimentin $(1: 100)$ for $1 \mathrm{~h}$ at room temperature. After washing in TBS three times, the cells were incubated in the dark for $1 \mathrm{~h}$ with secondary anti-mouse antibody-conjugated fluorescein isothiocyanate (FITC, Santa Cruz Biotechnology, Dallas, TX, USA) at a dilution of 1:500 in TBS/1\% BSA buffer, $\mathrm{pH}$ 7.6. Control reactions were incubated with PBS instead of primary antibody, followed by washing and incubation with a respective secondary antibody. Cells were washed another three times with TBS, and microscope slides were mounted in antifade solution with 4',6-diamidino-2-phenylindole (DAPI; Vectashield mounting medium, Vector Laboratories, Hercules, CA, USA). The samples were analyzed using a confocal laser scanning microscope (LSM) 510 (Zeiss). FITC was excited by argon ion laser set at $488 \mathrm{~nm}$, and the emitted light was filtered using a $505 \mathrm{~nm}$ (FITC) long pass filter. Sections were taken at approximately the mid-height level of the cells.

\section{Antibodies}

We used mouse anti-human monoclonal immunoglobulin G (lgG; Fc-specific) antibodies against the following proteins: ABCG2 (EMD Millipore, Billerica, MA, EUA), vimentin (Santa Cruz Biotechnology, California, USA), and anti-cytokeratin 3/12 (K3/12; RDI, Flanders, NJ, USA). 


\section{RESULTS}

\section{LSCs and corneal cell protein expression in hIDPSCs grown on plastic substrates in different culture media}

hIDPSCs have a differential response to marker protein expression when cultured in distinct culture medium for 7 days (Figure 2). hIDPSCs grown on plastic surfaces do not express ABCG2 when cultured in EpiLife, D-MEM/KO, KSFM, or SHEM (Figures 2A-A3); it is expressed in hIDPSCs only when hIDPSCs are cultured in basal culture medium (Figure 2A4). Interestingly, hIDPSCs cultured in D-MEM/KO and SHEM change their morphology after 7 days from fibroblast-like (Figure 2A4) to epithelial-like (Figures 2B1 and B3) and begin to express CK3/12. CK3/12 expression is not observed when hIDPSCs are cultured in EpiLife or KSFM and D-MEM/F-12 (Figures 2B, B2, and B4).

\section{Expression of LSCs and corneal cell markers in hIDPSCs grown in different culture media on AM}

Next, we verified the expression of these markers, and vimentin was verified in hIDPSCs grown on AM for 7 days (Figure 3). EpiLife was excluded from this experiment because of very low adherence and cell survival $(<50 \%)$ when grown in this medium on plastic surfaces.

Vimentin is a marker of MSCs, and its expression is observed in hIDPSCs grown in all tested culture media (Figures 3A-A3). It is positive in hIDPSCs maintained in D-MEM/F-12 and SHEM (Figures 3A and A1) but shows weak positivity in hIDPSCs cultured in KSFM or D-MEM/KO (Figures 3A2 and A3).

The ABCG2 antibody exhibits a strong positive reaction in hIDPSC cultured in D-MEM/F-12 or SHEM (Figures 3B and B1); however, it does not bind to hIDPSCs cultured in KSFM (Figure 3B2) and reacts weakly with hIDPSCs grown in D-MEM/KO (Figure 3B3). The anti-K3/12 antibody does not react with hIDPSCs cultured in D-MEM/F-12 or KSFM (Figures 3C and C2) and shows very weak immunopositivity in cells maintained in SHEM or D-MEM/KO (Figures 3C1 and C3).

\section{DISCUSSION}

The lack of human donors is a major obstacle when one wishes to obtain LSCs; however, cell culture techniques leading to expansion of these cells have been reported (about 23 population doublings), enabling the acquisition of large amounts of cells for tissue therapy ${ }^{(18)}$. Nevertheless, this culture technique leads to extensive manipulation of LSCs in vitro. The process of hIDPSC cultivation avoids multiple in vitro hIDPSC passages, thus minimalizing the risks of undesirable genetic transformation of cells ${ }^{(15,19)}$.

Previously, we conducted a preclinical study to treat LSCD in an experimental animal model by transplanting

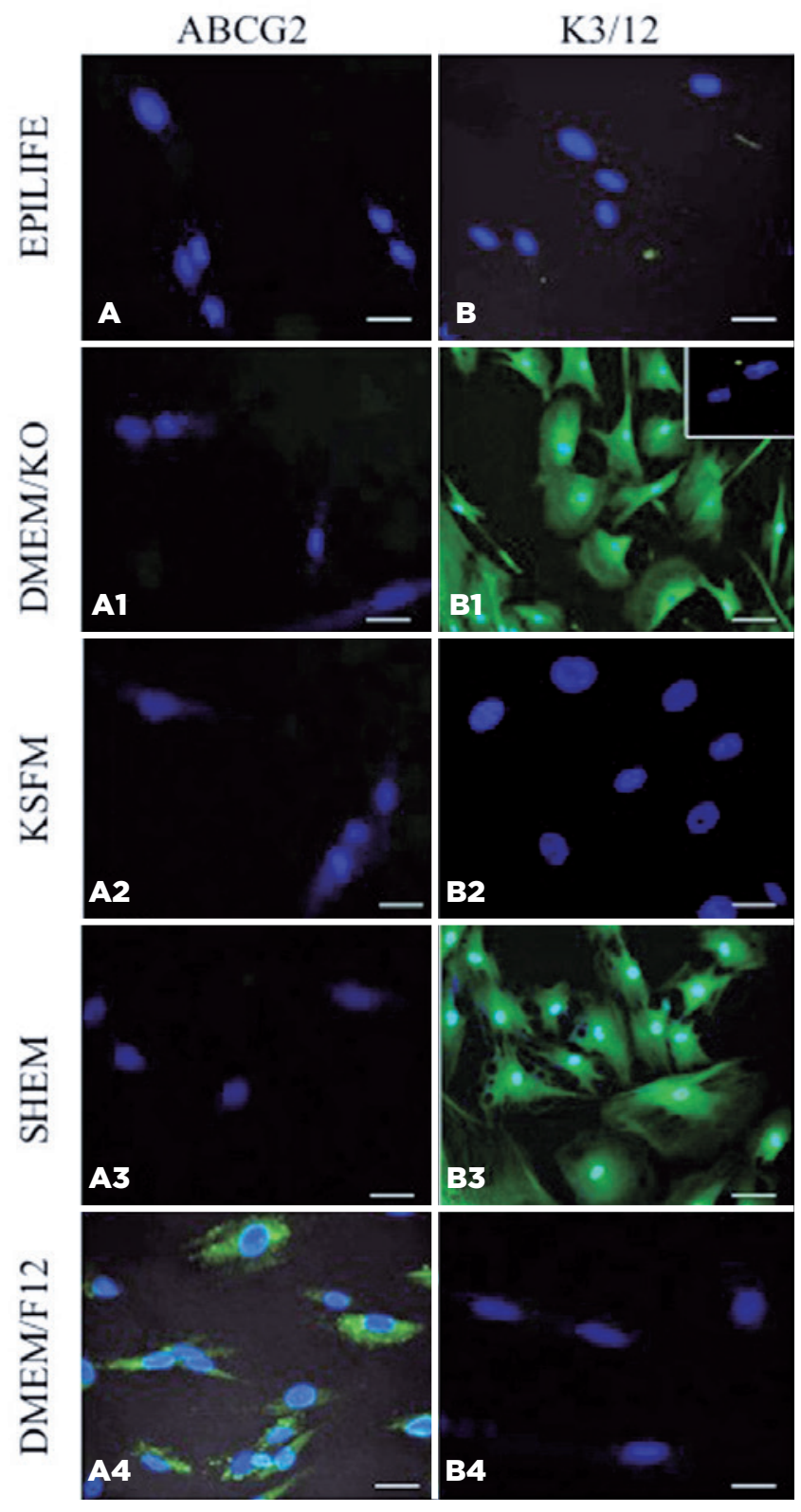

Figure 2. LSC and corneal cell protein expression in hIDPSCs grown for 7 days in different culture media on a plastic substrate. A-A3) Lack of ABCG2 expression in hIDPSCs cultured in EpiLife, D-MEM/KO, KSFM, or SHEM culture media. A4) ABCG2 expression in hIDPSCs cultured in basal culture media. Note the fibroblast-like cell morphology. B, B2, B4) Lack of CK3/12 expression in hIDPSCs. B1, B3) CK3/12 expression in hIDPSCs cultured in D-MEM/KO or SHEM. Note the epithelial-like cell morphology. The inset in B1) demonstrates secondary antibody control. Nucleus stained with DAPI (blue) epi-fluorescence (EF). Scale bars: A1-A4, B1, B2, B4 = $10 \mu \mathrm{m} ; \mathrm{A} 5, \mathrm{~B} 3, \mathrm{~B} 5=5 \mu \mathrm{m}$. 
hIDPSCs into burned rabbit eyes using cell sheet harvest technology ("UpCell Surface"), enabling the fabrication of viable, transplantable cell sheets ${ }^{(20,21)}$. However, the cell sheets were thin (once undifferentiated cells were used) and frequently broken, making such transplantation difficult and costly because several sheets had to be fabricated in order to reconstruct a single cornea. We feel that another cell substrate should facilitate undifferentiated hIDPSC transplantation into LSCD patients. The biological properties of AM were indicative for testing this membrane as a biological substrate for hIDPSCs in order to substitute the UpCell Surface system. However, our protocol required transplantation of a sheet of undifferentiated hIDPSCs; thus, we evaluated the ability of AM to maintain undifferentiated hIDPSC growth prior to transplantation.
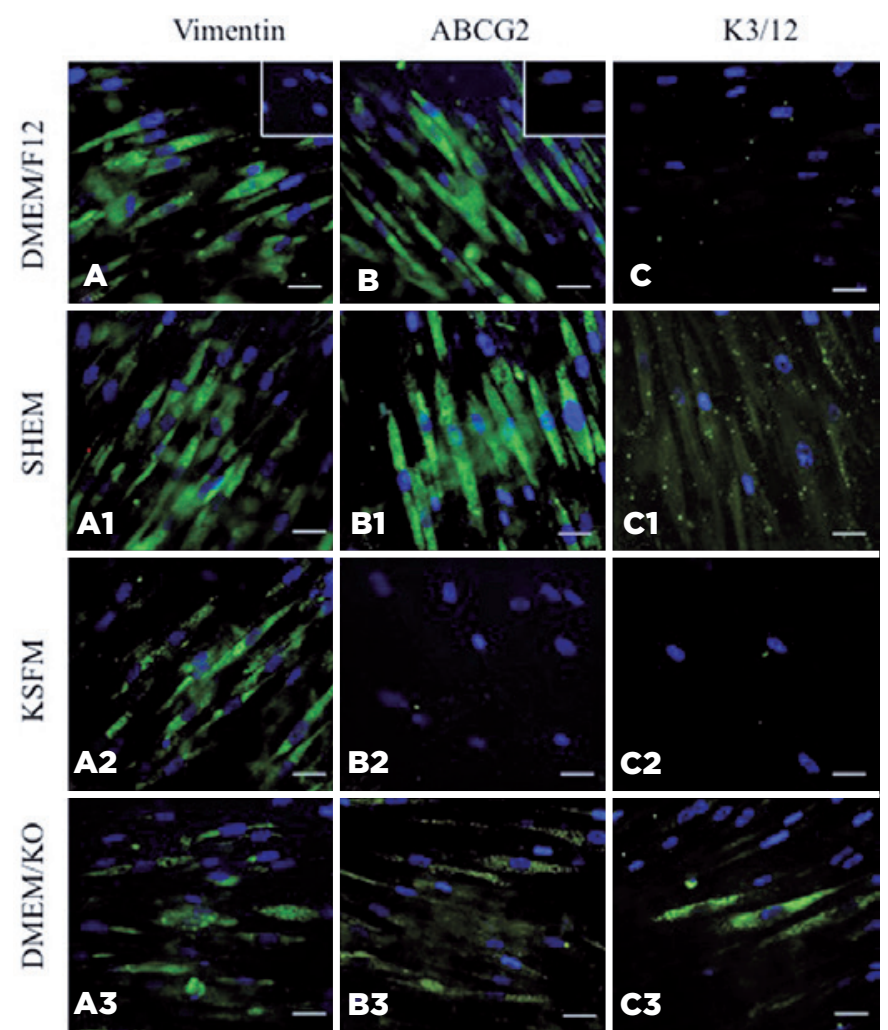

Figure 3. LSC and corneal cell marker expression in hIDPSCs grown on AM over 7 days in different culture media. A-A3) Vimentin expression in hIDPSCs grown in D-MEM/F-12, SHEM, KSFM, or D-MEM/KO culture media. B-B1) ABCG2 expression in hIDPSCs grown in basal culture media or SHEM. B2, B3) Lack of ABCG2 expression in hIDPSCs grown in KSFM or D-MEM/KO. C-C2) Lack of CK3/12 expression in hIDPSCs cultured in D-MEM/F-12, SHEM, or KSFM. C3) Rare hIDPSCs, which express CK3/12 when grown in D-MEM/KO. Note the fibroblast-like morphology of the cells. The insets in A) and B) are secondary antibody controls showing that the label is specific to the primary antibody. Nucleus stained with DAPI (blue) epi-fluorescence (EF). Scale bars: A1-A4, B1, B2, B4 $=10 \mu \mathrm{m}$; A5, B3, B5 $=5 \mu \mathrm{m}$.
The biological properties of AM (extracellular matrix integrity, growth factor composition, and high rate of cell attachment and proliferation) may be jeopardized depending on the de-epithelialization method ${ }^{(3)}$. Therefore, we used a very mild method of AM de-epithelialization in the present study to avoid complications ${ }^{(1)}$.

In order to improve cell culture conditions prior to hIDPSC transplantation, we tested their growth in several culture media used for ex vivo cultivation of limbal epithelial progenitor cells, such as SHEM, KSFM, and EpiLife $^{(22)}$. These culture media are completely different from the basal culture medium (D-MEM/F-12) used for routine in vitro hIDPSC cultivation, which usually keeps these cells undifferentiated. Moreover, we previously used D-MEM/KO culture medium for neuroepithelial but not epithelial differentiation; thus, we also verified the hIDPSC response to this culture medium ${ }^{(14)}$.

Overall, we demonstrated that hIDPSCs change their morphology and even differentiation rate in response to cell substrates and culture media. It appears that cells grown on conventional plastic surfaces in the presence of SHEM or D-MEM/KO are induced to differentiate, as shown by the morphological changes observed in hIDPSCs from the original fibroblast - to epithelial-like expression of CK3/12 protein and loss of ABCG2 expression - a marker of undifferentiated $\mathrm{LSCs}^{(20,22)}$. Conversely, cells grown on AM and cultivated in SHEM or D-MEM/KO present fibroblast-like morphology, express ABCG2, and do not express CK3/12-a marker of differentiated corneal cells. Basal culture medium D-MEM/F-12 is capable of supporting undifferentiated cells over 7 days independently of cell substrate. Several studies have shown ABCG2 protein expression exclusively in a subset of limbal epithelial cells, which localize to the basal corneal layer and are absent in limbal suprabasal and corneal epithelia. ABCG2+ corneal epithelium cells have enriched stem cell properties and higher p63 expression when compared with ABCG2-negative cells ${ }^{(23-25)}$. In addition, corneal and limbal cells express identical keratins, including large amounts of $\mathrm{K} 3$ and $\mathrm{K} 12$, which are markers of corneal-type differentiation; in contrast, the conjunctival epithelium produces minimal amounts of $\mathrm{K} 3 / \mathrm{K} 12$ keratin $^{(26-28)}$.

Vimentin, which is mainly expressed in undifferentiated MSCs, shows no change in expression in hIDPSCs grown on AM. Vimentin is necessary for the functioning of mesenchymal subpopulations of vimentin-rich repair cells, which are mediators of wound healing. Transient co-expression of vimentin and keratins in vivo during wound healing and in tissue culture of corneal epithelial cells has been reported previously ${ }^{(29-30)}$. 
EpiLife and KSFM are serum-free culture media that are efficient for the growth of $\mathrm{LSCs}^{(22)}$ and are not able to support adherence and survival of hIDPSCs, and SHEM, which is supplemented with $10 \%$ serum, demonstrate a similar capacity to that of basal culture medium for maintaining undifferentiated hIDPSCs.

Our present data suggest that AM, in combination with basal culture media (or SHEM), is able to support hIDPSCs in an undifferentiated state during the pre-transplantation period. Strong epithelial commitment of in vitro cultured hIDPSCs has also been demonstrated. hIDPSCs and LSCs are not identical, although they have similar neural crest origins and share similar properties. Studies are needed to examine the relationship between LSCs and hIDPSCs and other MSCs.

\section{REFERENCES}

1. Covre JL, Loureiro RR, Cristovam PC, Ricardo JR, Haapalainen EF, Gomes JÁ. [Comparison between amniotic membrane with and without epithelium as a support for human limbal epithelial cells cultured ex vivo]. Arq Bras Oftalmol. 2011;74(2):114-7. Portuguese.

2. de Melo GB, Gomes JA, da Glória MA, Martins MC, Haapalainen EF. [Morphological assessment of different amniotic membrane epithelial denuding techniques]. Arq Bras Oftalmol. 2007;70(3):407-11. Portuguese.

3. Zhang T, Yam GH, Riau AK, Poh R, Allen JC, Peh GS, et al. The effect of amniotic membrane de-epithelialization method on its biological properties and ability to promote limbal epithelial cell culture. Invest Ophthalmol Vis Sci. 2013;54(4):3072-81.

4. Larouche D, Paquet C, Fradette J, Carrier P, Auger FA, Germain L. Regeneration of skin and cornea by tissue engineering. Methods Mol Biol. 2009;482:233-56.

5. Pellegrini G, Traverso CE, Franzi AT, Zingirian M, Cancedda R, De Luca M. Long-term restoration of damaged corneal surfaces with autologous cultivated corneal epithelium. Lancet. 1997;349(9057):990-3.

6. Dua HS, Saini JS, Azuara-Blanco A, Gupta P. Limbal stem cell deficiency: concept, aetiology, clinical presentation, diagnosis and management. Indian J Ophthalmol. 2000;48(2):83-92.

7. Secker GA, Daniels JT. Corneal epithelial stem cells: deficiency and regulation. Stem Cell Rev. 2008;4(3):159-68.

8. Lenčová A, Pokorná K, Zajícová A, Krulová M, Filipec M, Holáň V. Graft survival and cytokine production profile after limbal transplantation in the experimental mouse model. Transpl Immunol. 2011;24(3):189-94.

9. Tan DT, Dart JK, Holland EJ, Kinoshita S. Corneal transplantation. Lancet. 2012;379(9827):1749-61.

10. Oie Y, Nishida K. Translational research on ocular surface reconstruction using oral mucosal epithelial cell sheets. Cornea. 2014;33: S47-52.

11. Oie Y, Nishida K. Regenerative medicine for the cornea. BioMed Res Int. 2013;2013:428247.

12. Kerkis I, Caplan Al. Stem cells in dental pulp of deciduous teeth. Tissue Eng Part B Rev. 2012;18(2):129-38.
13. Arno A, Smith AH, Blit PH, Shehab MA, Gauglitz GG, Jeschke MG. Stem Cell Therapy: A New Treatment for Burns? Pharmaceuticals (Basel). 2011;4(10):1355-80.

14. Kerkis I, Kerkis A, Dozortsev D, Stukart-Parsons GC, Gomes Massironi SM, Pereira LV, et al. Isolation and characterization of a population of immature dental pulp stem cells expressing OCT-4 and other embryonic stem cell markers. Cells Tissues Organs. 2006; 184(3-4):105-16.

15. Lizier NF, Kerkis A, Gomes CM, Hebling J, Oliveira CF, Caplan Al, et al. Scaling-up of dental pulp stem cells isolated from multiple niches. PLoS One. 2012;7(6):e39885.

16. Monteiro BG, Serafim RC, Melo GB, Silva MC, Lizier NF, Maranduba $\mathrm{CM}$, et al. Human immature dental pulp stem cells share key characteristic features with limbal stem cells. Cell Prolif. 2009; 42(5):587-94.

17. Forni MF, Loureiro RR, Cristovam PC, Bonatti JA, Sogayar MC, Gomes JA. Comparison between different biomaterial scaffolds for limbal-derived stem cells growth and enrichment. Curr Eye Res. 2013;38(1):27-34.

18. Lindberg K, Brown ME, Chaves HV, Kenyon KR, Rheinwald JG. In vitro propagation of human ocular surface epithelial cells for transplantation. Invest Ophthalmol Vis Sci. 1993;34(9):2672-9.

19. Kerkis I, Caplan Al. Stem cells in dental pulp of deciduous teeth. Tissue Eng Part B Rev. 2012;18(2):129-38.

20. Gomes JA, Geraldes Monteiro B, Melo GB, Smith RL, Cavenaghi Pereira da Silva M, Lizier NF, et al. Corneal reconstruction with tissue-engineered cell sheets composed of human immature dental pulp stem cells. Invest Ophthalmol Vis Sci. 2010;51(3):1408-14.

21. Nishida K, Yamato M, Hayashida Y, Watanabe K, Yamamoto K, Adachi E, et al. Corneal reconstruction with tissue-engineered cell sheets composed of autologous oral mucosal epithelium. N Engl ) Med. 2004;351(12):1187-96.

22. Loureiro RR, Cristovam PC, Martins CM, Covre JL, Sobrinho JA, Ricardo JR, et al. Comparison of culture media for ex vivo cultivation of limbal epithelial progenitor cells. Mol Vis. 2013;19:69-77.

23. de Paiva CS, Chen Z, Corrales RM, Pflugfelder SC, Li DQ. ABCG2 transporter identifies a population of clonogenic human limbal epithelial cells. Stem Cells. 2005;23(1):63-73.

24. Budak MT, Alpdogan OS, Zhou M, Lavker RM, Akinci MA, Wolosin JM. Ocular surface epithelia contain ABCG2-dependent side population cells exhibiting features associated with stem cells. J Cell Sci. 2005;118(8):1715-24.

25. Priya CG, Prasad T, Prajna NV, Muthukkaruppan V. Identification of human corneal epithelial stem cells on the basis of high ABCG2 expression combined with a large N/C ratio. Microsc Res Tech. 2013;76(3):242-8.

26. Wei ZG, Wu RL, Lavker RM, Sun TT. In vitro growth and differentiation of rabbit bulbar, fornix, and palpebral conjunctival epithelia. Implications on conjunctival epithelial transdifferentiation and stem cells. Invest Ophthalmol Vis Sci. 1993;34(5):1814-28.

27. Thoft RA, Wiley LA, Sundarraj N. The multipotential cells of the limbus. Eye (Lond). 1989;3(Pt 2):109-13.

28. Ebrahimi M, Taghi-Abadi E, Baharvand H. Limbal stem cells in review. J Ophthalmic Vis Res. 2009;4(1):40-58.

29. Menko AS, Bleaken BM, Libowitz AA, Zhang L, Stepp MA, Walker J. A central role for vimentin in regulating repair function during healing of the lens epithelium. Mol Biol Cell. 2014;25(6):776-90.

30. SundarRaj N, Rizzo JD, Anderson SC, Gesiotto JP. Expression of vimentin by rabbit corneal epithelial cells during wound repair. Cell Tissue Res. 1992;267(2):347-56. 